\title{
REMODELLING WORK-INTEGRATED LEARNING EXPERIENCES OF GRADE R STUDENT TEACHERS
}

\author{
M. Bouwer* \\ http://orcid.org/0000-0001-6408-837X
}

R. Venketsamy*

http://orcid.org/0000-0002-3594-527X

\section{K. Bipath*}

http://orcid.org/0000-0003-0588-9905

*Early Childhood Education

University of Pretoria

Pretoria, South Africa

\section{ABSTRACT}

There is a high demand by the Department of Basic Education (2011) to develop competent, flexible and knowledgeable teachers with bolstered attitudes and beliefs about their profession. Work Integrated Learning (WIL) is a crucial part in the Diploma in Grade R programme at a Private Higher Education Institution (PHEI) to prepare Grade R teachers. To prepare student teachers for the profession, they need quality experiences of WIL to apply their theoretical knowledge into authentic contextual situations. This study aimed to explore Grade R student teachers' experiences of WIL and their ability to transfer their knowledge and experiences into practice. Purposeful sampling was used to identify four student teachers as participants for this study. A qualitative case study research design, using in-depth interviews, observations and documentation was conducted. Data was analysed thematically through the lens of the situated learning theory by Jean Lave and Etienne Wenger (1991). Findings showed that Grade R student teachers experienced positive and negative aspects associated with their WIL practice. Their experiences related to the need for remodelling the WIL experience, which would entail moving from the periphery to full participation in classrooms, at least in the final year of their diploma programme. The use of Community of Practices (CoPs) in a WIL model would enhance practical experiences. Collaborative, comprehensive and critically constructive discussions after lessons are taught during WIL, would mould future Grade $\mathrm{R}$ teachers to embrace their working careers with competence and confidence.

Keywords: Work Integrated Learning, Grade R teachers, situated learning, legitimate peripheral participation, communities of practice 


\section{INTRODUCTION}

The demand for effective, competent and skilled teachers in South Africa remains a critical issue. Qualified, competent teachers are most influential in augmenting learners' learning and reaching educational results (Saracho 2013). Bowen and Drysdale (2017) state that serious questions arise globally about the state of work for university and college graduates in the context of Work-Integrated Learning (WIL). These graduates are entering into a precarious labour market that is filled with ambiguity and uncertainty, where they are competing for jobs or trying to develop skills. "The future of the profession rests on our ability to develop new ... methods to help individuals cope with the new organisation of work that is becoming increasingly less predictable, regulated, stable, and orderly" (Savickas 2019, n.p.).

It is vital that quality teacher education programmes are established to prepare student teachers for the demands of the workplace. The Department of Basic Education (DBE 2011), Spangenberg (2017) and Du Preez (2018), indicate that there is a demand for qualified and competent teachers. According to Gravett and Ramsaroop (2017), Initial Teacher Education (ITE) programmes do not prepare student teachers adequately for school realities, because programmes focus more on theoretical knowledge, without sufficient integration with practice (Darling-Hammond and Bransford 2005).

To prepare student teachers for the teaching profession, a crucial part of ITE programmes includes WIL. The significance of teacher education and the value of WIL have gained momentum. Aubusson and Schuck (2013) assert that the increase in research on teacher education and preparation is due to a lack of qualified teachers who are proficient in teaching in challenging situations. Limited studies focus on WIL implemented at different education levels such as a diploma, or towards Grade R (Billett 2011; Fleming and Haigh 2018). To provide student teachers with experiential knowledge, practical wisdom and a positive professional identity, the three-year Diploma in Grade R programme offered by the Private Higher Education Institute (PHEI) places student at schools for WIL each year. In this article, we extract the dimensions of students' experiences and reflect on how students could be better supported through a remodelled WIL framework.

\section{LITERATURE REVIEW}

\section{Explanation of work integrated learning}

The Council of Higher Education (CHE) acknowledges that learning in higher education should be "less didactic and more situated, participative and real-world orientated" (Winberg et al. 2011, 4). According to the Minimum Requirements for Teacher Education Qualifications 
(MRTEQ), WIL is compulsory/mandatory for all ITE programmes (DHET 2015). Student teachers are provided with the opportunity to participate in teaching and learning and gain experience in an authentic context.

The term WIL has been used interchangeably throughout literature with cooperative education, teaching practice and experiential learning (Winberg et al. 2011). Smith (2012) defines WIL as a curriculum design where individuals experience the professional context relevant to their study and work-related futures. This definition of WIL focuses on the role it plays in the curriculum and the context to prepare individuals for the workplace. Similarly, Kiggundu and Nayimuli (2009) view WIL in South Africa as a time when individuals receive training and experience in the specific workplace to apply theory in practice-based contexts.

From the definitions above, it is evident that the "integration" of theory and practice is a crucial characteristic of WIL. WIL goes beyond merely placing students in an authentic, physical environment and applying knowledge to practice. It is a compulsory part of the programme and focuses on the formation of new knowledge within practice, and acquiring skills that apply to the profession. In this article, WIL is referred to as the crux of teacher education programmes, which offers student teachers with the opportunity to integrate theoretical knowledge within contextual situations. WIL is therefore structured, intentional and provides a bridge for student teachers between academic practice and professional future in becoming a teacher.

\section{The value of WIL for student teachers}

The MRTEQ policy (DHET 2015) provides particular conditions for the design of teacher education programmes. One of the key principles that underpin ITE programmes is practical learning, which encompasses WIL.

The kind of practical learning that is acquired and strengthened during WIL is learning in practice and learning from practice in a situated learning environment (i.e., a classroom or school) (DHET 2015). Learning from practice occurs when student teachers study the practice in an authentic classroom, for example, by observing the teaching strategies used by a qualified mentor teacher. Learning in practice enables student teachers to experience the classroom by planning and teaching lessons, and implementing assessments (Assan 2014). A recent strategic policy framework document for the South African teacher education sector introduces the notion of teaching schools into the public education system of the country (DBE 2011). The plan is that such schools will be affiliated to universities in the same way that teaching hospitals are affiliated to universities where health practitioners are educated. Teaching schools are regarded as "safe" learning spaces where student teachers are mentored and coached and they 
are "experimental", argue Henning, Petker, and Petersen (2015).

The MRTEQ policy (DHET 2015) includes eleven competencies that newly qualified teachers are expected to obtain throughout a teacher education programme. During WIL, student teachers observe mentor teachers' teaching and gain in-depth knowledge of the content to be taught. According to Darling-Hammond and Bransford (2005), student teachers reinforce and synthesise concepts during WIL by learning in practice.

Communication skills are developed during WIL by providing student teachers with the opportunity to teach in front of learners and their mentor teacher, consequently building student teachers' confidence to teach (Billett 2011). Student teachers collaborate with their mentor teachers and the assessors from their higher education institutions about best teaching practices and how to communicate with other stakeholders at the school. Literacy and numeracy skills have to be developed, as well as information technology (IT) skills, by taking on some of the administrative roles and responsibilities of a teacher, for example, IT and ICT prepares teachers for virtual environments especially during COVID19. Student teachers interact with the curriculum by planning and teaching lessons through WIL.

According to Nkambule (2017), student teachers need to experience different school contexts in order to become aware of various contextual issues. During WIL, student teachers learn about the practices and procedures of the school and classroom and compare them to other schools.

Student teachers are also provided with the opportunity to implement the classroom management strategies observed. Student teachers observe and recognise that assessment takes place continuously (Marais and Meier 2004). They are also provided with the opportunity to implement assessment in the classroom, with support from the mentor teacher.

The Department of Education (DBE) and the South African Council of Educators (SACE) expect student teachers to learn and practise appropriate work ethics and professionalism and to adhere to the school's values (Jusoh 2013). Mentor teachers should also display good teaching practices, work ethic and professionalism in order for student teachers to learn from them. WIL provides student teachers with the opportunity to reflect on the school, classroom, and their own teaching. Reflection plays a vital role during WIL and encourages student teachers to improve on their practice (Baeten and Simons 2016).

\section{Challenges experienced by student teachers during WIL}

Student teachers are placed at schools both urban and rural schools for their WIL practice to apply educational theory in different situations and school contexts. According to Bhargava (2009), student teachers encounter difficulties during WIL concerning classroom management, 
contextual challenges and support from the mentor teacher and lecturer. Kiggundu and Nayimuli (2009); Abongdia, Adu, and Foncha, (2015) also agree that classroom management and contextual factors affect student teachers' WIL experience.

In South Africa, discipline is a challenge and many student teachers struggle to manage and discipline learners (Abongdia et al. 2015). Marais and Meier (2004) emphasise that student teachers are anxious and concerned about maintaining discipline and learner control before starting their WIL. If conflict thus arises in the values and discipline styles between student teachers and learners, it may lead to a negative interpretation of their WIL experience. They therefore need to receive guidelines from the school on its values and code of conduct, as well as support from the mentor teacher on how to manage the classroom effectively (Kiggundu and Nayimuli 2009).

Koross (2016) and Kiggundu and Nayimuli (2009) noticed that schools did not openly welcome or orientate student teachers of their learning culture and environment Some schools also lack resources such as books, a library, and teaching and learning materials, which make it difficult for student teachers to teach. Furthermore, student teachers did not know how to relate to the learners and maintain discipline (Mokhele 2007). Negative experiences with mentor teacher highlighted that student teachers seemed to have been exploited and abused, with regard to work overload (Kiggundu and Nayimuli 2009). A lack of effective mentoring during WIL poses challenges to student teachers and influences the way they see their role and career as a teacher. Both positive and negative experiences moulded the student teachers' character and identity and certainly prepared them for the life of a teacher.

\section{The role of support during WIL}

Preparing student teachers for the authentic classroom remains a challenge. To minimise these challenges, WIL should be structured, well monitored and supervised with the necessary support from mentor teachers and university staff (Ulla 2016). Through their WIL experience, student teachers would become resilient to the challenges and find creative and innovative ways to persevere in their chosen profession (De Wever et al. 2016). Aglazor (2017) states that the quality of student teachers' experiences during WIL is primarily determined by the support from the university, mentor teachers and schools.

Jusoh (2013) emphasises that mentor teachers are the most influential factor in student teachers' WIL experiences. Support is essential since mentor teachers empower student teachers to observe and emulate good practice and teaching skills. Kiggundu and Nayimuli (2009) and Du Plessis et al. (2010) found that some mentor teachers were willing to help and provide valuable advice to student teachers. This motivated student teachers to teach and build 
their self-image and confidence, as well as learn effective practices to implement in their own teaching.

Student teachers, in addition to support from mentor teachers, need adequate support and supervision from mentor lecturers/assessors. The purpose of supervision and assessment from assessors during WIL is to provide support, thus encouraging best practice in student teachers (Abongdia et al. 2015).

\section{THEORETICAL FRAMEWORK}

Lave and Wenger's situated learning theory emphasises that "there is no activity that is not situated" (1991, 33). Prescott and Cavanagh (2008) support the view that learning is a social activity. The more an individual's participation in the context increases, the more he/she understands the practices and experiences in this context. For learning to take place, this theory focuses on the interaction and participation of individuals in an authentic context (Wenger 1998).

The individual is central to the situated learning theory by engaging in social communities. Two key notions of the situated learning theory are highlighted to reinforce the understanding of student teachers' experiences, namely, "legitimate peripheral participation" and “communities of practice" (Gowlland 2014, 761).

\section{Legitimate peripheral participation}

"Legitimate peripheral participation (LPP) is the position that individuals adopt as newcomers in a context in which they will begin a process of learning" (Gowlland 2014, 761). Lave and Wenger (1991) recommend that "newcomers" should start by being slowly introduced to authentic (legitimate), peripheral activities, and progressively be assigned to more significant activities.

In this study, student teachers are referred to as the "newcomers". They are required to participate in activities during their WIL practice, such as observing the mentor teacher, planning and teaching lessons, assessing and implementing classroom management strategies. Student teachers' participation during WIL is dependent on the opportunities they receive for learning in and from practice. Patel (2017) asserts that learning is rooted in individuals' opportunities to participate in practice, as is their level of engagement. Handley et al. (2006) explain that a person first participates at the periphery in the community with limited participation. When individuals are allowed more responsibility and adopt the practices of others, they become competent and obtain full participation (Handley et al. 2006). 


\section{Communities of Practice}

A community of practice $(\mathrm{CoP})$ is a group of individuals who share a common passion or concern, thereby interacting with one another to expand their knowledge, skills and expertise (Lave and Wenger 1991). Individuals in a CoP discuss aspects of a subject and share ideas and activities, as well as ways of communicating and acting in the profession (Morrell 2003). Hawkins and Rogers (2016) discovered that working in a CoP helped student teachers to develop professionally and that CoPs can be customised to pre-service teacher training.

Our research draws on the situated learning theory by enabling student teachers to participate and socially interact in the context, such as a school and classroom environment, to learn. Student teachers may form a CoP with their mentor teacher, other Grade R educators at the school, mentor lecturer or with their peers. The members in the CoP share a common interest such as their experiences of WIL, teaching Grade R learners or planning Grade R lessons. The interaction and participation in the context allow student teachers to move from the periphery to be more engaged in the CoP. CoPs require full participation of teaching and learning in the classroom and would therefore prepare the students to be more confident when teaching their own classes. Figure 1 provides a visual representation of student teachers' development during WIL where they move from the periphery to full participation.

Throughout the WIL practice, student teachers are gradually entrusted with more tasks of teaching and assessing learners. The more opportunities they are given, the more opportunities to enhance their confidence in teaching (Gowlland 2014). There is also value in the assessments and feedback on student teachers' lessons from the mentor teachers, assessors and peers during WIL. Collaborations between the student teacher and mentors allow a student teacher to progress and advance from the periphery to the centre of the $\mathrm{CoP}$ by improving on specific areas in their practice.

\section{RESEARCH METHODOLOGY}

To elicit student teachers' experiences of WIL, the researcher was guided by an interpretivist paradigm. This provided the researcher to explore participants' various experiences of their WIL practice, from their viewpoint. A qualitative approach was therefore adopted using a case study methodology. This offered the researcher to recognise and comprehend participants' experiences in the context (Yin 2011). Purposeful sampling was used to identify four, secondyear student teachers as participants (P1-P4) studying a Grade R programme offered by a PHEI. The PHEI focused on distance education, therefore each participant completed their WIL practice at a different school in Gauteng (S-A to S-D), within a four-week period as specified by the PHEI. 


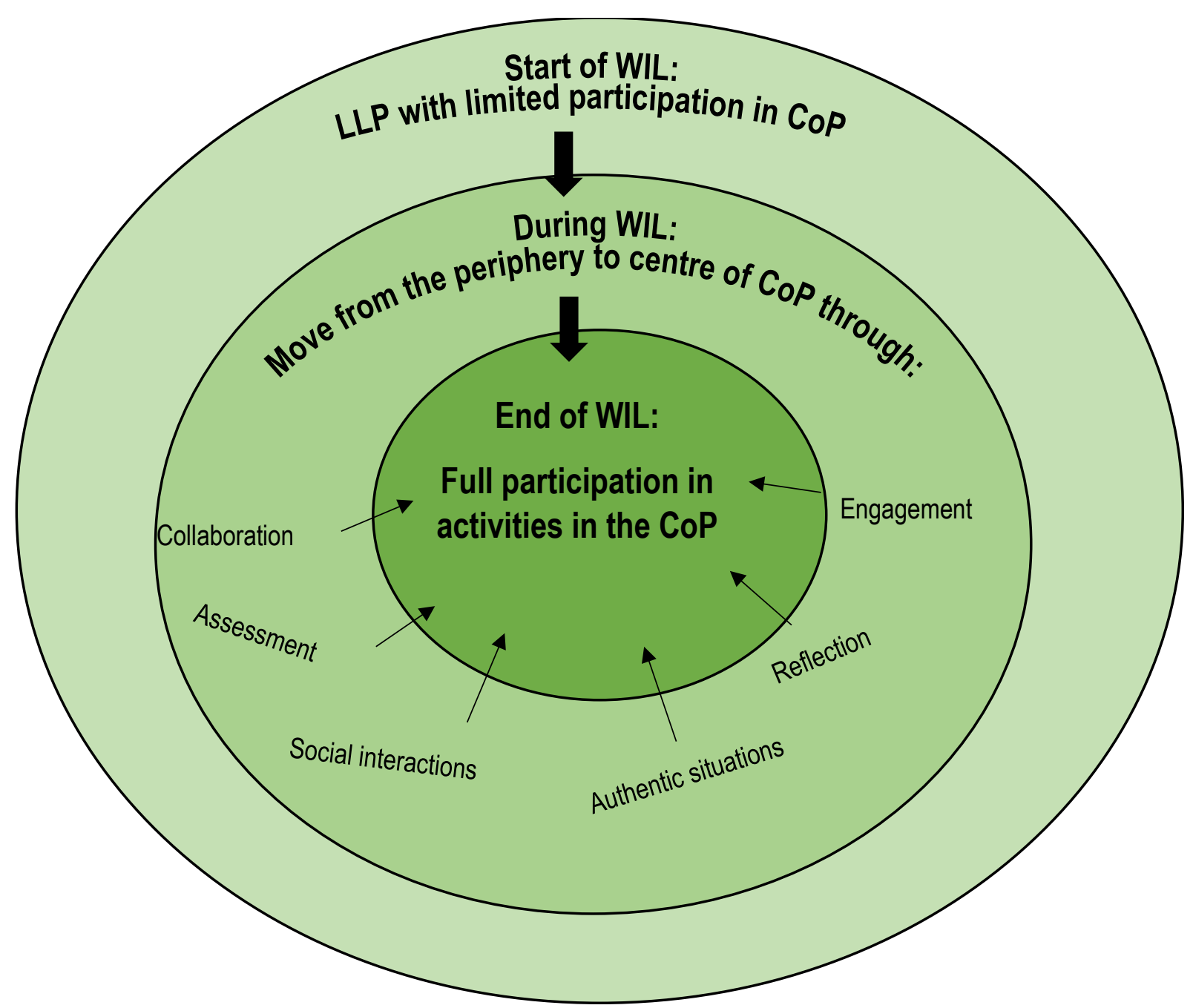

Figure 1: Situated Learning Theory - Progression of student teachers from the periphery to full participation in the CoP

Data was gathered through semi-structured interviews, classroom observation and documentation. Interviews were the primary data collection method and took place at the school where the participant completed their WIL practice. The 30 minute interviews took place after the assessment. The reason for interviewing participants individually was to ensure that student teachers' experiences could be explored broadly. The use of various data collection methods as well as participants who were placed at different schools with varied contexts also assisted in the validation of the data through triangulation.

Classroom observation was conducted by one of the researchers through observing Grade R lessons presented by each participant during WIL. Documents such as participants' WIL assignments, reflection notes and the assessor's assessment rubrics were also perused. Thematic data analysis was conducted by identifying common patterns (McMillan and Schumacher 2014). 
The researcher ensured trustworthiness by letting participants verify the accuracy of the transcripts of the interview and the field notes through member-checking. Ethical approval was obtained by the University of Pretoria. Participation in the study was voluntary and informed consent was obtained from the participants. Their anonymity, confidentiality and privacy were also guaranteed, and deception was avoided.

\section{RESEARCH FINDINGS AND DISCUSSION}

Student teachers' experiences of WIL were categorised into broad themes: 1) Reflections of student teachers' experiences, and 2) Moving from the periphery to the centre through adequate support. To support the themes that emerged, verbatim quotes from the data are used as evidence in the results. The first theme consisted of four categories.

\section{Reflections of student teachers' experiences}

Student teachers needed to know what WIL means and what WIL entails since it offers them an authentic interface between being a student and becoming a member of the teaching profession (Msangya, Mkoma, and Yihuan 2016). Reflections at the end of lesson plans proved that students are aware of the templates for planning lessons as well as rubrics used for assessment of lectures. It was not certain if they could assess each other's lessons.

\section{Knowledge of WIL}

The definition of WIL utilised in this study was seen as a fundamental part of teacher education to enable student teachers to integrate theoretical knowledge within a contextual situation. The findings of this study showed that participants understood WIL as the application of theoretical knowledge into practice-based contexts. P2 indicated, "WIL is ... practising. Putting what you read in the modules into practice ... or classroom practice." P4 similarly referred to WIL as being more practical by learning in practice: "I understand that it is the practical part of work, when we are supposed to go in the classroom so that we learn about the teaching and learning in a school and classroom".

P3 however referred to WIL as learning from practice, i.e., from the mentor teacher, and focused on the opportunity it provides to student teachers to experience the classroom:

"It is about experiencing Grade R teaching ... you are learning from your mentor, so you are experiences some of the things you don't understand. As for me, I know nothing about teaching. So I started knowing last year when I started my practical." 


\section{Benefits of WIL}

WIL has significant benefits for student teachers in becoming qualified and competent Grade R teachers. P3 emphasised the value of WIL by focusing on the experience student teachers receive for the profession. P3 mentioned,

"I'm still a student, I can go and finish my Diploma. And if we are not doing WIL, I won't be able to know what to do ... so I won't be having experience. So WIL is helping when it comes to experience."

Participants also emphasised the value of WIL by learning about learners' needs and development and how to teach in a Grade R classroom. P1 mentioned the importance of developmentally appropriate practices in teaching learners during WIL, as it "helps a teacher to learn the different kinds of learners that are in the class". P4's response was similar as she indicated that through WIL she learned how to teach learners in the classroom: "The area I can say is in the classroom. Specifically, in the classroom, how to teach, according to their development." The knowledge she gained from the modules enabled her to integrate and adapt to learners' developmental needs and abilities, and thus develop pedagogical content knowledge. Rahman et al. (2010) agree that WIL provides student teachers with pedagogical content knowledge on how to teach, organise and adapt concepts to diverse learners' interests and abilities. It is therefore imperative that student teachers experience setting up of a learning environment and an understanding of developmentally appropriate practices for teaching Grade R learners.

Participants also indicated that WIL has increased their confidence in teaching. According to Norton (2017), one of the most important aspects of being a teacher is to teach a subject with confidence. P3 indicated that through WIL, she gained the confidence to teach:

"I was not having the confidence of standing in front of people, kids or my mentor teacher when she is observing me. Now I can say that I have improved because I can stand freely and express myself."

Confidence as a teacher is an essential skill in WIL.

\section{Theory into practice experiences}

Student teachers explained their "theory to practice" experiences by relating them to the knowledge gained from participating during WIL through observing their mentor teacher, teaching and interacting with learners and the school environment. When asked how participants experienced WIL, they mentioned that they learnt about the pedagogies in Grade 
$\mathrm{R}$, the Grade $\mathrm{R}$ learners and how to transform knowledge into practice. Participants indicated that theories came to life when they experienced them physically in a Grade R classroom. P1 mentioned that "when you are doing practicals, you see that theory doesn't happen in a simple way". She expressed that it is only through practice that you realise that teaching Grade R children is the art of responsiveness and reciprocity. The teacher needs to be "hands-on" (P1).

The process for student teachers to observe their mentor teachers is vital during WIL in order to learn how to put the theory into practice. Participants mentioned that they received sufficient opportunities to learn from practice by observing their mentor teacher. P3 stated that "I observed [the mentor teacher] for the first week, even for the second ... so while she was teaching I was still observing". When student teachers continuously observe their mentor teacher throughout WIL practice, they are able to reflect critically on what strategies are working and what is not working with regard to teaching, assessment and discipline (Baeten and Simons 2016).

After mentor observation, student teachers needed to learn in practice by teaching and implementing what they had seen in the classroom. It was noticeable during the interviews with participants that they were not provided with enough opportunities to teach different kinds of lessons, i.e., teacher-guided and child-initiated activities in Grade R. They taught mostly teacher-guided activities which ranged over the three subjects: Numeracy, Literacy and Life Skills. P1 mentioned: "I think I did teach language, mathematics ... and other lessons. So three lessons." P4 stated: "In my second year, per day we have three [lessons] for four weeks". Participants were not able to experience teaching a full day, which is an important part of learning how to become a teacher (Aglazor 2017). They experienced alienation and wished that they could be provided with more opportunities to teach. P2 stated that the school and mentor teacher "must give us more opportunities in all areas like teaching, playing with them". P4 also expressed that the teacher should have trusted her teaching ability: "I think to support me differently, they must give me the opportunity to teach every day, the full day, to gain more experience". More opportunities to teach enable student teachers to gain more experience in teaching and move from the periphery to the centre of the CoP.

Although participants received limited experience to teach, most of them indicated that they gained an understanding of how to teach Grade R learners through play pedagogies. P1 asserted: "I have to allow my kids to play in order for them to learn. So, I didn't think they are learning by playing." P4 similarly mentioned: "When I came to school, I learned that Grade R is about playing while they learn". Participants recognised that play pedagogies should be implemented in the Grade R classroom and that these form a vital part of teaching learners. The National Association for the Education of Young Children (2009) concurs that teaching in 
Grade $\mathrm{R}$ should be facilitated through play and integrated within and across domains.

Participants mentioned that they recognised learners' diverse abilities and backgrounds in the classroom. P4 mentioned that through her experience of WIL, she "learnt about the children, their background, cultural and their behaviours. And that learners are not the same ... because I thought that children were supposed to be the same." Similarly, P1 stated that she identified "the barriers in the learning areas for the learners that can't cope and understand". Participants thus experienced that teaching has to be adapted accordingly to accommodate all learners. Learners' different developmental levels and behaviours were, however, a challenge for P2. She mentioned: "The only challenge is ... the learners. They are not the same every day." Participants recognised the demanding but important role of a Grade R teacher in assisting learners to reach their full potential.

\section{Context in student teachers' WIL practice}

The requirements from the PHEI stipulated that student teachers in the Diploma in Grade R programme should spend three weeks of WIL in their first year and four weeks in their second year. To allow participants to develop professionally as teachers and improve their Content Knowledge (CK) and Pedagogical Content Knowledge (PCK), continuous development and exposure to a variety of schools, classrooms and learners are required (Hattingh and De Kock 2008).

Three of the participants (P1, P3 and P4) mentioned that they were doing their WIL at the same school as their previous WIL practice in year one. This is important to note as these participants found it difficult to compare the learners, school, staff and classroom to another school. P2, however, was the only participant who completed her WIL practice at another school, in order to gain more experience of the learners, school and how different teachers teach Grade R learners.

Most of the schools where the selected participants completed their WIL practice had English as the Language of Learning and Teaching (LoLT). Majority of the Grade R learners came from townships in the area with a different home language than the LoLT of the school. P1 mentioned that learners struggled to verbalise their responses in English during numeracy lessons: “... learners don't understand mathematics language to verbalise their answers”. This encouraged participants during WIL to include activities and strategies that could support learners with a language barrier. Worksheets, written books and teachers' planning were evidence of the creativity that students showed to accommodate all learners in their class with different home languages.

The availability of resources at the school influenced participants' WIL experiences and 
consequently, how they teach. Without adequate resources for Grade R learners, participants were unable to teach at a concrete level. P3 mentioned the limited resources at her school. P3 emphasised that "different teaching materials are important for learning". The participant used the chalkboard most of the time and taught her lessons mostly at an abstract level. Although P4 completed her WIL at a well-resourced school, she indicated that the school could have supported her more "by showing her how to use the various LTSM [learner-teacher support materials]".

\section{Moving from the periphery to the centre through adequate support}

Student teachers' experiences during WIL are dependent on the quality of support provided to them (Aglazor 2017). Participants were asked about the kinds of support they received during WIL from the mentor teachers and schools. According to Liu (2014), the mentor teachers' role is to provide support to student teachers during WIL practice, through opportunities to learn in and from practice. One way how the mentor teacher guided P4 was in her planning: "The teacher showed me how to plan from the daily programme a weekly plan, monthly plan and daily lesson plan”. Similarly, P3 specified that her mentor teacher was adaptive in assisting her in completing lesson plans according to the template by the PHEI: "When I showed my mentor the template required by my college, she helped me write the lesson plan".

Participants' reflections on the support provided by the mentor teachers were mostly positive. Two of the four participants mentioned that the support they received in year one compared to year two was the same (P1, P4). Two participants indicated that they received more support in year two during WIL than in year one (P2, P3). P2 mentioned: "year two was more supportive". Even though P2 mentioned that the support from the mentor teacher is more, she indicated that her WIL experience could be strengthened by learning how to conduct assessments in Grade R, "They must help us how to assess them [learners]". According to the MRTEQ policy (DHET 2015), one of the eleven competencies that teachers should acquire is to implement assessment in the classroom.

Mentor teachers provided further support by giving feedback to participants on their lessons. However, P3 mentioned that her mentor teacher corrected her by saying "you do not have to do it this way. Of course I learnt from her whilst she was teaching so I was observing and learning something." According to Jusoh (2013), one of the roles of mentor teachers is to provide immediate feedback to student teachers on their teaching to strengthen learning practices in the context.

WIL may be seen as a very emotional and stressful time for student teachers (Liu 2014). P1 indicated that her mentor teacher always "asks me how is it going, are you coping ... do you 
have any challenges in the class". P4 mentioned that she received emotional support from her mentor teacher when she was feeling stressed and when the WIL assessor did not arrive as planned, to assess her. "So I was crying and she supported me".

Student teachers also need adequate support and supervision from the mentor lecturer or assessor (PHEI). The purpose of supervision and support from assessors during WIL is to assist and encourage best practice in student teachers (Abongdia et al. 2015). Assessors provided verbal and written feedback on areas where participants should improve on their practice. It was noticed that there was inconsistency with assessors when providing written feedback to participants. Some assessors would provide constructive written feedback, whereas others only completed the rubric without any written feedback. Written feedback provides the PHEI with an evaluation of aspects to strengthen in student teachers' teaching and WIL experiences.

\section{RECOMMENDATIONS}

This study focused on Grade R student teachers' experiences of WIL, their ability to transfer knowledge into practice and their suggestions for remodelling WIL. To ensure Grade R student teachers' experiences of WIL are positive for teaching and learning to occur, firstly, CoPs need to be formed to create safe learning spaces for students. Clear, meaningful and constructive feedback on the assessments of lessons can be discussed within the CoPs and students can learn about the strengths and weaknesses of all their lessons, allowing for feedback orally, and to minimalise discrepancies in the feedback. Improvement for transformative pedagogy as well as responsive teaching methods could be discussed after the lessons are taught within the CoP. Mentor teachers also need to provide student teachers with the opportunity to teach all subjects for a full school day (teacher-directed and child-initiated lessons with assessment practices included) in order for them to move from the periphery (observation only) to full participation (competent teaching practices) at the end of the diploma and their WIL practice.

Secondly, assessors and mentor teachers should have had the necessary training regarding verbal and written feedback on student teachers' lessons. The PHEI will need to have a training session where the operations of the CoP are fully understood and conducted professionally. The mentors also need to realise their motivational role in bolstering attitudes and beliefs of teachers. Finally, institutions should place students at different schools for each WIL period so that they can grow from the different CoPs and the varied teaching and learning experiences derived.

Remodelling the WIL framework to include CoPs would ensure that student teachers work collaboratively to become competent, knowledgeable, flexible, reflective and skilful teachers who are able to apply theoretical knowledge into practices. Teamwork and collective thinking 
about best teaching practices would allow for a quality WIL experience. Quality WIL experiences would bolster the attitudes, beliefs, and competencies (ABCs) of future teachers to enjoy their great career-life roles (Hartung 2018). Young graduates would embrace their teaching career with confidence and competence, given a rich, varied and improved WIL experience. They would thus be most influential in augmenting learners' learning and reaching educational results that South Africa desires.

\section{CONCLUSION}

We conclude by briefly foregrounding some of the study's implications for practice. This study aimed to explore the experiences of Grade R diploma student teachers' during WIL. Due to a scarcity of research to prepare competent and motivated Grade R student teachers for the teaching profession, it was essential to rethink how quality practical teaching experiences could enhance the competencies of teachers.

The reflective teaching and learning experiences, the support student teachers received from mentors and their plea for full-day teaching displays that these students felt alienated. They needed to be entrusted with teaching, assessment and learner development. Thus, remodelling the WIL experience to centre students' experiences on the pedagogy of reciprocal and responsive classroom learning as well as ensuring that $\mathrm{CoP}$ constructive discussions and reflections for collaboration, growth and optimal teaching practice take place, would prove beneficial for future Grade R teachers.

\section{REFERENCES}

Abongdia, J., E. Adu, and J. Foncha. 2015. "Pre-service teachers' challenges during teaching practice in one university in the Eastern Cape, South Africa." International Journal of Educational Science 11(1): 50-56. https://doi.org/10.1080/09751122.2015.11890374.

Aglazor, G. 2017. "The role of teaching practice in teacher education programmes: Designing framework for best practice." Global Journal of Educational Research 16(2): 101-110. https://doi.org/10.4314/gjedr.v16i2.4.

Assan, T. E. B. 2014. "Work integrated learning (WIL): A phenomenographic study of student-teachers' experiences." Mediterranean Journal of Social Sciences 5(7): 300-306. doi: https://doi.org/10.5901/mjss.2014.v5n7p300.

Aubusson, P. and S. Schuck. 2013. "Teacher education futures: Today's trends, tomorrow's expectations." Teacher Development 17(3): 322-333. https://doi.org/10.1080/ 13664530.2013.813768.

Baeten, M. and M. Simons. 2016. "Innovative field experiences in teacher education: Student-teachers and mentors as partners in teaching." International Journal of Teaching and Learning in Higher Education 28(1): 38-51. https://eric.ed.gov/?id=EJ1106337.

Bhargava, A. 2009. "Teaching practice for student teachers of B.Ed. Programme issues, predicaments and suggestions." Turkish Online Journal of Distance Education 10(2): 101-108. https://dergipark.org.tr/en/pub/tojde/issue/16912/176416. 
Billett, S. 2011. Curriculum and pedagogic bases for effectively integrating practice-based experiences. Sydney: Australian Learning and Teaching Council Sydney.

Bowen, T. and M. T. D. Drysdale. (Ed.). 2017. Work-Integrated Learning in the 21st Century. Global perspectives on the future. United Kingdom: Emerald Publishing.

Darling-Hammond, L. and J. Bransford. 2005. Preparing teachers for a changing world: What teachers should learn and be able to do. San Francisco: John Wiley \& Sons.

DBE see Department of Basic Education.

De Wever, B., R. Vanderlinde, M. Tuytens, and A. Aelterman. (Ed.). 2016. Professional learning in Education. Challenges for teacher educators, teachers and student teachers. Gent. Academia Press.

Department of Higher Education and Training. 2015. Revised policy on the minimum requirements for teacher education qualifications. 596(38487). Pretoria: Government Printers.

Department of Basic Education. 2011. Integrated Strategic Planning Frameworkfor Teacher Education and Development in South Africa, 2011-2025. Pretoria: Government Printers.

DHET see Department of Higher Education and Training.

Du Plessis, E. C., P. Marais, A. van Schalkwyk, and F. Weeks. 2010. "Adapt or die: The views of Unisa student teachers on teaching practice at schools." Africa Education Review 7(2): 323-341. https://doi.org/10.1080/18146627.2010.515401.

Du Preez, M. 2018. "The factors influencing mathematics students to choose teaching as a career." South African Journal of Education 38(2): 1-13. https://doi.org/10.15700/saje.v38n2a1465.

Fleming, J. and N. J. Haigh. 2018. "Using sociocultural insights to enhance work-integrated learning." Higher Education, Skills and Work-Based Learning 8(4): 395-407. https://doi.org/10.1108/HESWBL-09-2017-0071.

Gowlland, G. 2014. "Apprenticeship as a model for learning in and through professional practice." In International handbook of research in professional and practice-based learning, ed. S. Billett, C. Harteis, and H. Gruber. Netherlands: Springer.

Gravett, S. and S. Ramsaroop. 2017. "Teaching schools as teacher education laboratories." South African Journal of Childhood Education 7(1): 527. https://doi.org/10.4102/sajce.v7i1.527.

Handley, K., A. Sturdy, R. Fincham, and T. Clark. 2006. "Within and beyond communities of practice: Making sense of learning through participation, identity and practice." Journal of Management Studies 43(3): 641-653. https://doi.org/10.1111/j.1467-6486.2006.00605.x.

Hartung, P. J. 2018. "Life design: A unifying paradigm for international Counselling Psychology." Paper prepared for Division 16. Presidential Address at the $29^{\text {th }}$ International Congress of Applied Psychology. Montreal, Quebec, Canada.

Hattingh, A. and D. M. de Kock. 2008. "Perceptions of teacher roles in an experience-rich teacher education programme." Innovations in Education and Teaching International 45(4): 321-332. https://doi.org/10.1080/14703290802377216.

Hawkins, S. and M. P. Rogers. 2016. "Tools for reflection: Video-based reflection within a preservice community of practice." Journal of Science Teacher Education 27(4): 415-437. https://doi.org/10.1007/s10972-016-9468-1.

Henning, E., G. Petker, and N. Peterson. 2015. "University-affiliated schools as sites for research learning in pre-service teacher education." South African Journal of Education 35(1): 1-8. https://doi.org/10.15700/201503070014.

Jusoh, Z. 2013. "Teaching practicum: Student teachers' perspectives." Research, Renovation and Reinforcement: Enhancing Quality in Language Education, 886-874. http://litu.tu.ac.th/FLLT2013/www.fllt2013.org/private_folder/Proceeding/865.pdf

Kiggundu, E. and S. Nayimuli. 2009. "Teaching practice: A make or break phase for student teachers." South African Journal of Education 29(3): 345-358. https://doi.org/10.15700/saje.v29n3a129. 
Koross, R. 2016. "The student teachers' experiences during teaching practice and its impact on their perception of the teaching profession." International Journal of Education \& Multidisciplinary Studies 5(2): 76-85. https://doi.org/10.21013/jems.v5.n2.p3.

Lave, J. and E. Wenger. 1991. Situated learning: Legitimate peripheral participation. Cambridge: Cambridge University Press.

Liu, S. 2014. "Excellent mentor teachers' skills in mentoring for pre-service teachers." International Journal of Education 6(3): 29-42. https://doi.org/10.5296/ije.v6i3.5855.

Marais, P. and C. Meier. 2004. "Hear our voices: Student teachers' experiences during practical teaching." Africa Education Review 1(2): 220-233. https://doi.org/10.1080/18146620408566281.

McMillan, J. H. and S. Schumacher. 2014. Research in Education: Evidence-Based Inquiry. 7th Ed. Essex: Pearson Education.

Mokhele, P. R. 2007. "The teacher-learner relationship in the management of discipline in public high schools." Journal of African Education Review 3(1-2): 148-159. https://doi.org/ 10.1080/18146620608540448.

Morrell, E. 2003. "Legitimate peripheral participation as professional development: Lessons from a summer research seminar." Teacher Education Quarterly 30(2): 89-99. https://www.jstor.org/stable/23478471.

Msangya, B. W., S. L. Mkoma, and W. Yihuan. 2016. "Teaching practice experience for undergraduate student teachers: A case study of the Department of Education at Sokoine University of Agriculture, Tanzania." Journal of Education and Practice 7(14): 113-118. https://eric.ed.gov/?id=EJ1103037.

National Association for the Education of Young Children. 2009. A position statement of the National Association for the Education of Young Children: Developmentally appropriate practice in early childhood programs serving children birth through age eight. Washington, DC: NAEYC.

Nkambule, T. 2017. "Student teachers' perceptions of a Wits rural teaching experience project: What to learn and improve." South African Journal of Higher Education 31(1): 191-206. https://doi.org/ 10.20853/31-1-901.

Norton, S. J. 2017. "Primary mathematics trainee teacher confidence and its relationship to mathematical knowledge." Australian Journal of Teacher Education 42(2): 47-61. https://doi.org/ 10.14221/ajte.2017v42n2.4.

Patel, C. 2017. Situated learning: Legitimate peripheral participation. London: Taylor and Francis.

Prescott, A. and M. Cavanagh. 2008. "A situated perspective on learning to teach secondary mathematics." Navigating Currents and Charting Directions: 407-414. http:/hdl.handle.net/10453/11370.

Rahman, F. A., J. Scaife, N. A. Yahya, and H. Ab Jalil. 2010. "Knowledge of diverse learners: Implications for the practice of teaching." International Journal of Instruction 3(2): 83-96. http://www.e-iji.net/dosyalar/iji_2010_2_5.pdf.

Saracho, O. N. 2013. "Early childhood teacher preparation programmes in the USA." Early Child Development and Care 183(5): 571-588. https://doi.org/10.1080/03004430.2012.673488.

Savickas, M.L. 2019. "Designing a self and constructing a career in post-traditional societies." Keynote address at the $43^{\text {rd }}$ International Association for Education and Vocational Guidance Conference, Bratislava, Slovakia.

Smith, C. 2012. "Evaluating the quality of Work-Integrated Learning curricula: A comprehensive framework." Higher Education Research \& Development 31(2): 247-262. https://doi.org/ 10.1080/07294360.2011.558072.

Spangenberg, E. 2017. "The interplay between theory and practice: Mathematics pre-service teachers' learning experiences at a teaching school." The Independent Journal of Teaching and Learning 12(2): 92-112. https://hdl.handle.net/10520/EJC-c512fa4fd.

Ulla, M. B. 2016. "Pre-service teacher training programs in the Philippines: The student-teachers 
practicum teaching experience." EFL Journal 1(3): 235-250. https://doi.org/ 10.21462/eflj.v1i3.23.

Wenger, E. 1998. Communities of practice: Learning, meaning, and identity. Cambridge, UK: Cambridge University Press.

Winberg, C., P. Engel-Hills, J. Garraway, and C. Jacobs, C. 2011. Work-integrated Learning: Good practice guide-HE Monitor No. 12. Pretoria: Council on Higher Education (CHE).

Yin, R. K. 2011. Qualitative research from start to finish. 1st Ed. New York: Guilford. 